\title{
Fallout from the Mutual Fund Trading Scandal
}

Todd Houge
Jay Wellman

\begin{abstract}
In September 2003, several prominent mutual fund companies came under investigation for illegal trading practices. Allegations suggested these funds allowed certain investors to profit from short-term trading schemes at the expense of other investors. Surprisingly, regulatory authorities have known for more than two decades of the potential for such abuses, yet have taken limited steps to correct the problem. We explore investor reaction to the scandal by measuring assets under management, stock returns, and performance. Mutual funds managed by investigated firms show a substantial decline in post-announcement assets under management. These firms also experienced significantly negative announcement-period returns. Finally, we discuss several policy suggestions to prevent future trading abuses and provide direction for future research.
\end{abstract}

KEY WORDS: fair value pricing, late trading, market timing, mutual funds, redemption fees, scandal, trading abuse.

\section{Introduction}

On September 3, 2003, New York Attorney General (NYAG) Elliot Spitzer revealed that his office had "obtained evidence of widespread illegal trading schemes that potentially cost mutual fund shareholders billions of dollars annually." 1 This announcement launched a formal inquiry into the trading practices of several prominent mutual fund companies. Although the true depth of the problem was unknown, Spitzer alleged that the mutual fund industry operates on a double standard by allowing certain clients to benefit from short-term market

Todd Houge is an Assistant Professor of Finance at the University of Iowa.

Jay Wellman is an Assistant Professor of Finance at Binghamton University. Professors Houge and Wellman both received $M B A$ and Ph.D. degrees from the University of Iowa. timing strategies and illegal after-hours trading to the detriment of other investors.

The NYAG investigation initially focused on the activities of hedge fund Canary Capital Partners, LLC, its managers, and four mutual fund companies with which it had formal trading agreements: Bank of America, Janus Capital Group, Bank One, and Strong Capital Management. As the probe unfolded, it became clear that the scope and magnitude of the scandal was more far reaching than originally believed. The fallout continues to reverberate across the industry. As of December 31, 2004, the Securities and Exchange Commission (SEC) and several state attorneys general have formally indicted or investigated at least 25 mutual fund families. ${ }^{2}$ Settlements stemming from these charges total more than $\$ 3.1$ billion in fines and restitution.

Asset management firms compete aggressively for wealthy clients and institutional investors, offering lower fees and access to special services. By and large, this preferential treatment does not generally harm other investors. More troubling is the revelation that certain fund investors were allowed to employ rapid trading strategies which knowingly dilute shareholder returns. Even worse is the notion that some funds actively solicited and profited from these relationships. Mutual funds originally developed as a vehicle to allow small investors to efficiently invest in liquid, diversified, and professionally-managed portfolios. The industry is built on trust. These abuses suggest that some firms regard mutual fund investors as an exploitable asset.

We begin by exploring the policies that allowed questionable trading schemes to proliferate throughout the fund industry. Surprisingly, regulatory authorities knew of these potential trading abuses for more than two decades, yet took limited measures to prevent them. We suggest that the 
problems currently shaking the industry could have been avoided with changes to the pricing rules used to determine daily net asset values (NAV) of openended mutual funds.

We also examine investor and market reaction to announcements of an investigation into the trading practices at individual fund families. For publicly traded asset management companies, we report a strong negative reaction to the disclosure of a formal mutual fund inquiry. In addition, we document a significant decline in assets under management for funds associated with the scandal. This decline in assets translates into nearly $\$ 1.0$ billion of combined annual revenue losses across the investigated funds.

Finally, we consider several policy suggestions to prevent future trading abuses. Regulatory changes must restore investor confidence while maintaining the competitiveness of mutual funds against a growing number of low-cost alternatives. Some recent changes, such as redemption fees and shortterm trading restrictions, are unpopular with investors and simply push the trading abuses off onto other funds. Alternatively, we advocate a uniform system of fair value pricing for daily NAVs that adjusts security prices based on all available information. We also suggest that linking asset management revenues more directly to fund performance may avert future abuses by aligning the interests of management with fund shareholders.

The rest of the paper is organized as follows. Section "Evolution of a scandal: Late trading v. market timing" examines the extent of trading abuses within the mutual fund industry and the regulatory environment that allowed them to proliferate. Section "Investor and market reaction" studies the reaction of the market and fund investors to investigation announcements at individual fund companies. Section "Solutions to prevent market timing and future trading abuses" discusses several policy solutions to eliminate trading abuses.

\section{Evolution of a scandal: Late trading v. market timing}

The scandal that rocked the mutual fund industry in the fall of 2003 involved two separate forms of trading abuse: late trading and market timing. Al- though they differ in their legality, both activities harm fund investors.

\section{Late trading}

The Investment Company Act of 1940 regulates mutual fund valuation. ${ }^{3}$ Rule $22 \mathrm{c}-1$, which was adopted by the SEC in 1968, requires open-ended mutual funds to measure daily net asset values with "forward" pricing. ${ }^{4}$ Under this approach, funds must issue and redeem shares at the NAV first computed following the order. As a result, almost all mutual funds in the U.S. calculate daily NAVs at the 4:00 p.m. (Eastern Time) market close. Orders received after 4:00 p.m. are executed the following day.

Late trading refers to the sale or purchase of fund shares after the closing deadline, but at the 4:00 p.m. price. NYAG Elliot Spitzer compares late trading to "betting on a horse race after the horses have crossed the finish line." 5

Late trading is a clear violation of Rule 22c-1 and is illegal. To successfully trade a fund after hours, an investor must collude with a broker, dealer, or mutual fund company. Investors who engage in late trading exploit information revealed after the market close that is likely to materially impact the next day's NAV. This strategy generates short-term gains for the investor and additional trading expenses for the fund. Since expenses are spread evenly across all investors, other fund investors pay most of the trading costs created by the short-term traders.

Perhaps the most egregious example of late trading involves Canary Capital Partners and its relationship with several brokerage and mutual fund companies. According to the complaint filed by the New York Attorney General, Canary engaged in late trading with dozens of mutual funds on a daily basis from March 2000 until July 2003. ${ }^{6}$ These relationships, mostly with brokerage intermediaries, allowed after-market trades as late as 9:00 p.m., often unbeknownst to the traded fund.

One fund company however, Bank of America (BOA), provided Canary with late trading capacity in its own Nations line of mutual funds. In exchange, Canary deposited several million dollars of long-term assets in Nations bond funds. BOA also installed its proprietary trading system in Canary's offices so the hedge fund could more effectively 
enter its late trades. As if that was not enough, Canary leveraged these activities by trading on margin borrowed from BOA. Thus, Bank of America actually loaned Canary the capital necessary to make illegal trades in its own funds.

Late trading activities are not limited to a few unscrupulous firms. In Senate testimony, the SEC noted that more than $25 \%$ of broker-dealers responding to an information request reported that customers periodically were allowed to place or confirm mutual fund orders after hours and receive the 4:00 p.m. NAV. ${ }^{7}$

Using daily fund flows for a subset of mutual funds, Zitzewitz (2003b) finds statistically significant evidence of late trading in the international funds for 15 out of 50 fund families. He estimates that late trading cost shareholders in international equity funds an average of 5 basis points and shareholders in domestic equity funds 0.6 basis points in 2001. If consistent across the industry, these dilution rates suggest annual shareholder losses of almost $\$ 400$ million due to late trading.

\section{Market timing}

Market timing involves rapid buying and selling of funds to take advantage of short-term swings in net asset value. These trades are less of a bet on the future direction of the market than an arbitrage strategy based on stale prices. An active security may trade several times per minute when the market is open, but with a thinly traded security, several hours or even days may pass between trades. Thus, price quotes are not updated regularly and may become stale. Funds holding securities that do not often trade near the 4:00 p.m. market close, such as international, small-company stock, and high-yield bond funds, are highly susceptible to stale prices. Market timers exploit these structural inefficiencies in fund pricing.

To illustrate, Figure 1 presents trading differences across three time zones: New York, London, and Tokyo. When the London market closes at 4:30 p.m., it is 11:30 a.m. in New York. As the Tokyo exchange closes at 3:00 p.m. on day $t+1$, it is still 1:00 a.m. in New York on day $t$. Thus, prices of London and Tokyo-listed securities are $41 / 2$ and 15-hours-old, respectively when U.S. funds calculate daily NAVs at 4:00 p.m.
When market quotations are readily available, Section 2a-41 of the 1940 Act instructs funds to price their portfolios at current market value. If a current market quote is unavailable, the statute allows funds to estimate the security's fair value as determined in good faith by the fund's board of directors. Under fair value pricing, a stale closing price is adjusted to reflect the value one might reasonably expect to receive upon the current sale of the security. Thus, fair value pricing allows mutual funds to adjust stale net asset values to reflect available market information.

The SEC reaffirmed fair value pricing in a noaction letter against two Putnam mutual funds in $1981 .^{8}$ At the time, Putnam estimated the NAV of its international funds using local closing prices for all securities except when an extraordinary event occurred after the close. This ruling implies that Putnam, the SEC, and presumably other mutual funds were aware that standard practices for computing NAV could result in stale and possibly exploitable prices. Unfortunately, the industry lacks

\section{Overlap of International Equity Market Trading}

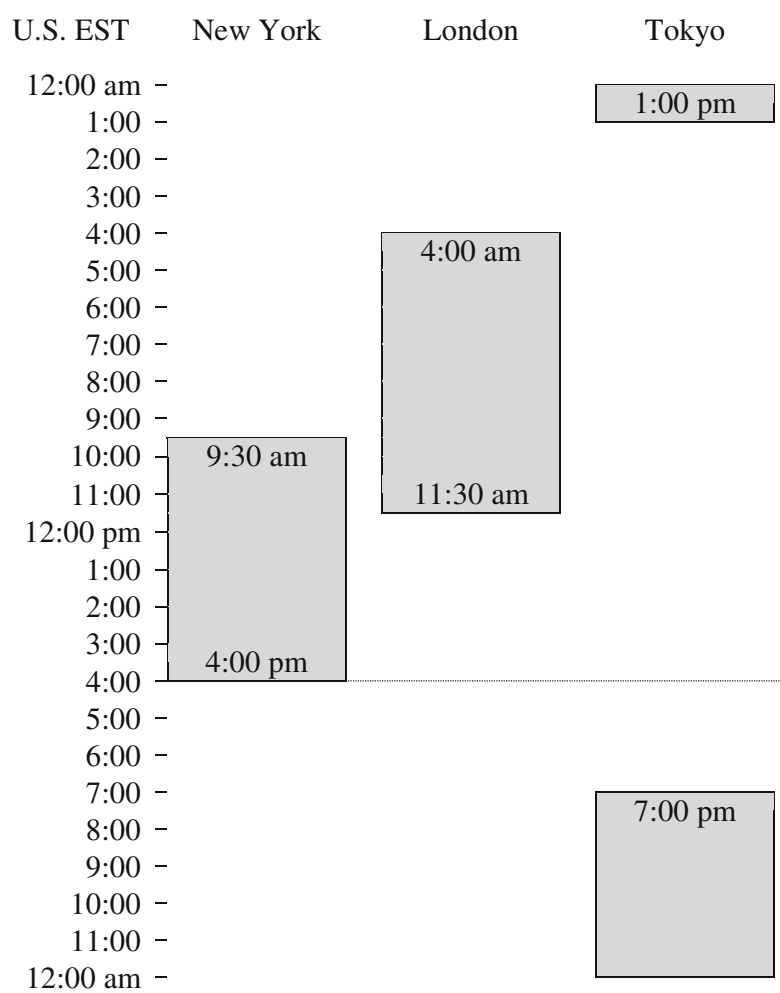

Figure 1. Overlap of international equity market trading. 
a single standard for determining fair value in good faith. Without a clear and concise framework, very few funds have elected to employ fair value pricing, even during extreme market events.

Market timers utilize information produced during U.S. trading hours that is not fully reflected in daily NAVs. By observing large index movements or trends in similar types of securities, timers are able to predict the direction of future NAV changes. For example, the positive correlation across global financial markets implies that large increases in U.S. equity indexes are often followed by positive changes across international equity markets. Thus, a market timer could purchase international equity funds following a sharp rise in U.S. markets and sell these funds when U.S. markets trend down. This strategy generates significantly positive excess returns because the timer is able to trade at stale net asset values. Moreover, the strategy is perfectly legal.

Open-ended mutual funds provide investors with daily liquidity by standing ready to issue or redeem shares at the daily net asset value. Market timing strategies take advantage of this essentially free liquidity to dilute the returns of other shareholders. A timer who purchases fund shares just prior to an increase in NAV earns a positive return even though her investment was not fully invested in the market by the fund. The trading profits earned by market timers come at the expense of other long-term investors. The SEC has known of this problem for decades, yet until recently, has chosen to ignore it.

Evidence of market timing is widely documented in the literature, especially among international mutual funds. ${ }^{9}$ Zitzewitz (2003a) reports that traders engaging in international fund arbitrage earn abnormal returns as high as $35-70 \%$ per year. These opportunities are not limited to international funds. Profitable trading strategies exist for almost every fund category. Zitzewitz estimates that market timing dilutes fund returns by as much as $2 \%$, or up to $\$ 6$ billion per year. Greene and Hodges (2002) also suggest that timers impose additional costs on shareholders, such as higher processing fees, larger cash holdings, increased turnover, and greater transaction costs.

Zitzewitz also finds that market timing activity actually increased following its documentation in the literature. As investors exploit arbitrage strategies, market prices typically adjust until the strategy is no longer profitable. Fund timing, however, takes advantage of structural inefficiencies in NAV pricing rather than market inefficiencies. Trading on this knowledge does not eliminate its profitability. Many investors likely became aware of this trading strategy only once it was reported in the media. In addition, we suggest the possibility that the industry and regulatory reaction to these events gave investors the perception that market timing was an accepted norm of behavior.

Most funds responded to the heightened scrutiny in the academic and popular press with measures to curb timing activities, such as imposing trade limits, initiating short-term redemption fees, and/or actively discouraging rapid trading in the prospectus. We are perplexed by the industry's preference for fees and monitoring over fair value pricing. Fair value pricing essentially eliminates market timing activity by making it unprofitable and less predictable. Redemption fees, trade limits, and monitoring discourage market timing activity, but do not completely solve the problem. It is also difficult to ensure that these policies are applied equally to all investors. Zitzewitz (2003a) remarks that funds using these policies are open to the criticism that they want to preserve the right to selectively allow certain investors to actively trade their funds.

As allegations of trading abuses surfaced in September 2003, it became clear that some mutual funds did not uniformly apply these policies to all shareholders. Several mutual funds actively sold timing capacity in their funds in exchange for large deposits of sticky long-term assets. In its November testimony before the U.S. Senate, the SEC disclosed that half of the 88 fund families it surveyed, representing more than $90 \%$ of all mutual fund assets, had formal market timing arrangements. Elliot Spitzer has compared this policy to "a casino saying that it prohibits loaded dice, but then allowing favored gamblers to use loaded dice, in return for a piece of the action."

As previously noted, market timing itself is not illegal. Most of the formal charges brought by the SEC and NYAG are against funds that secretly allowed select investors to rapidly trade the portfolio despite statements banning the practice in the prospectus. A double standard that favors one investor at the expense of another is illegal and undermines the credibility of the industry.

In February of 2004, the SEC formally indicted Columbia Management Advisors, the investment advisor to more than 140 mutual funds in the 
Columbia family. ${ }^{11}$ The complaint alleged that between 1998 and 2003, Columbia entered into at least nine market-timing arrangements with brokers, hedge funds, and individual investors. Over the 5-year period, these investors made hundreds of round-trip trades (purchases and redemptions) across 16 different funds totaling more than $\$ 2.5$ billion.

Internal documents reveal these aggressive timers were a common source of conflict between portfolio managers and the sales force. ${ }^{12}$ The Columbia Young Investor Fund was a frequent target of three timers who together carried out more than 250 round-trip trades in the fund from 1998 to 2003. Sadly, the Young Investor Fund is marketed as an educational fund for children, and a portion of the fund's expenses support a website that teaches children and teens about saving money and financial markets. It is unclear whether teaching about market timing was one of the educational objectives of the fund.

\section{Investor and market reaction}

The belief that mutual fund companies will uphold their fiduciary duties to investors is an important underpinning of the entire fund industry. Formal SEC investigations and allegations of trading abuse clearly call this belief into question. To explore the fallout from the mutual fund trading scandal, we examine the reaction of financial markets and fund investors to these accusations.

Table I identifies 25 mutual fund families as the target of formal trading abuse investigations by the SEC, NYAG, or other regulatory body since September of 2003. We obtained this list of funds from Morningstar and The Wall Street Journal. Initial news dates represent the first day that news of the investigation became publicly available. These disclosures are released through a variety of sources, including news articles, company press releases, and regulatory actions.

As of December 31, 2004, formal charges have been brought against 17 fund families. State and federal regulators have reached settlements in 16 cases with a combined payout of more than $\$ 3.11$ billion. These settlements include civil penalties, fines, and investor restitution. The NYAG has also aggressively negotiated long-term fee reduction agreements on behalf of mutual fund shareholders. To date, Alliance Capital Management has agreed to the largest settlement, paying a $\$ 100$ million civil penalty, $\$ 150$ million in shareholder restitution, and agreeing to a 5 -year reduction in mutual fund fees by $20 \%$ or approximately $\$ 350$ million. ${ }^{13}$

The monetary effects of these settlements are certainly significant, yet they likely pale in comparison to the damage caused by lost investor confidence. Table II reports the announcement period returns, change in market capitalization, and abnormal trading volume upon the initial disclosure that a mutual fund family was under investigation for alleged trading abuses. We present these results for the 15 parent firms that trade publicly on U.S. exchanges. ${ }^{14}$

As expected, the market responded very negatively to these investigation disclosures. The average firm in Table II experienced statistically significant 3-day returns of $-5.14 \%$ and elevated levels of trading volume. The announcement returns were negative for $100 \%$ of the parent firms in the sample. On average, these firms lost more than $\$ 1.35$ billion of market capitalization over the 3day announcement period. The extent of the allegations as well as the diversification of the parent firms likely impacts the scope of the market's reaction. Several firms, such as Bank of America and ING Groep NV are large financial conglomerates, while other firms, like Janus Capital Group and Federated Investors are primarily asset management companies.

Table III reports the average monthly returns across five categories of funds managed by investigated and non-investigated fund families. Returns are measured from January 2001 until December 2003. It is interesting to note that the investigated fund families manage almost $25 \%$ of all mutual funds in the sample. This fact demonstrates the scope of the industry investigation.

We observe that the performance of domestic and international equity funds managed by the investigated families lags the performance of comparable funds at non-investigated families. These fund categories are precisely where we would expect to find market timing activities most prevalent during the sample period. Investigated equity funds underper- 
TABLE I

Mutual fund investigations and settlements

\begin{tabular}{|c|c|c|c|c|}
\hline Fund Family & Initial News Date & Formal Charges & Settlement (\$ millions) & Parent Firm \\
\hline Janus & $9 / 3 / 03$ & $\mathrm{Y}$ & $\$ 226.0$ & Janus Capital Group \\
\hline Nations & $9 / 3 / 03$ & $\mathrm{Y}$ & $\$ 455.0$ & Bank of America \\
\hline One Group & $9 / 3 / 03$ & $\mathrm{Y}$ & $\$ 90.0$ & Bank One \\
\hline Strong & $9 / 3 / 03$ & $\mathrm{Y}$ & $\$ 175.0$ & Private \\
\hline Franklin Templeton & $9 / 3 / 03$ & $\mathrm{Y}$ & $\$ 73.0$ & Franklin Resources \\
\hline Gabelli Funds & $9 / 3 / 03$ & $\mathrm{~N}$ & & Gabelli Asset Mgmt. \\
\hline Putnam & $9 / 19 / 03$ & $\mathrm{Y}$ & $\$ 110.0$ & Marsh \& McLennan \\
\hline Alliance Bernstein & $9 / 30 / 03$ & $\mathrm{Y}$ & $\$ 600.0$ & Alliance Capital \\
\hline Alger & $10 / 3 / 03$ & $\mathrm{Y}$ & $\$ 0.4$ & Private \\
\hline Federated & $10 / 22 / 03$ & $\mathrm{~N}$ & & Federated Investors \\
\hline PBHG Funds & $11 / 13 / 03$ & $\mathrm{Y}$ & $\$ 260.0$ & Old Mutual PLC \\
\hline Loomis Sayles & $11 / 13 / 03$ & $\mathrm{~N}$ & & CDC Asset Mgmt. \\
\hline Excelsior/US Trust & $11 / 14 / 03$ & $\mathrm{~N}$ & & Charles Schwab \\
\hline Fremont & $11 / 24 / 03$ & $\mathrm{Y}$ & $\$ 4.2$ & Private \\
\hline AIM/Invesco & $12 / 2 / 03$ & $\mathrm{Y}$ & $\$ 451.5$ & Amvescap PLC \\
\hline MFS & $12 / 9 / 03$ & $\mathrm{Y}$ & $\$ 350.0$ & Sun Life Financial \\
\hline Heartland Advisors & $12 / 11 / 03$ & $\mathrm{Y}$ & & Private \\
\hline Seligman & $1 / 7 / 04$ & $\mathrm{~N}$ & & Private \\
\hline Columbia & $1 / 15 / 04$ & $\mathrm{Y}$ & $\$ 220.0$ & FleetBoston Financia \\
\hline Scudder & $1 / 23 / 04$ & $\mathrm{~N}$ & & Deutsche Bank AG \\
\hline PIMCO & $2 / 13 / 04$ & $\mathrm{Y}$ & $\$ 68.0$ & Allianz Group \\
\hline RS Investments & $3 / 3 / 04$ & $\mathrm{Y}$ & $\$ 30.0$ & Private \\
\hline ING Investments & $3 / 11 / 04$ & $\mathrm{~N}$ & & ING Groep NV \\
\hline Evergreen & $8 / 4 / 04$ & $\mathrm{~N}$ & & Wachovia \\
\hline Sentinel Group & $10 / 7 / 04$ & $\mathrm{Y}$ & $\$ 0.7$ & Private \\
\hline Total & & & $\$ 3113.8$ & \\
\hline
\end{tabular}

Sources: Morningstar.com, The Wall Street Journal, the SEC, and the NYAG office.

Note: The data includes mutual fund families with known investigations and/or settlements related to market timing or late trading. The initial news date is the first date in which an investigation is mentioned in the press. Settlement amounts include civil penalties, fines, investor restitution, and lowering of future asset management fees. Information as of December 31, 2004.

form non-investigated equity funds by a statistically significant $0.15 \%$ per month or $1.80 \%$ per year. This result is not explained by differences in average expense ratios between the two groups, and it is consistent with allegations that market timing activities potentially dilute the returns of shareholders.

Figure 2 compares the cumulative fund flows between the investigated and non-investigated fund families for 6 months after the initial announcement. Following the disclosure of a formal investigation, investors began to reduce their holdings within the fund complexes. Meanwhile, investor contributions to non-investigated fund families grew over the same period. Six months after the initial announcements, the assets of investigated funds were reduced by almost $13 \%$ relative to the non-investigated funds. This differential translates into a considerable loss of revenue. In unreported results, we estimate that the average fund managed by an investigated firm lost approximately $\$ 14.0$ million in assets over the 6-month window after announcement. These redemptions translate into more than $\$ 844$ million in lost fee income across all funds managed by these companies over the 6-month period. ${ }^{15}$ The long-term present value of this lost revenue likely far exceeds the total settlements paid by the industry. 
TABLE II

Announcement returns and abnormal trading volume for U.S.-traded firms under investigation

\begin{tabular}{|c|c|c|c|}
\hline Investigated Firm & $\begin{array}{l}\text { Announcement } \\
\text { Return }(\%)\end{array}$ & $\begin{array}{c}\text { Market Capitalization } \\
\text { Change (millions) }\end{array}$ & $\begin{array}{c}\text { Abnormal Trading } \\
\text { Volume }(\%)\end{array}$ \\
\hline Alliance Capital & -5.03 & $\$ 133.3$ & 153.6 \\
\hline Allianz Group & -0.84 & $\$ 2348.6$ & -27.3 \\
\hline Amvescap PLC & -6.11 & $\$ 341.6$ & 103.1 \\
\hline Bank of America & -1.78 & $\$ 2585.0$ & 18.8 \\
\hline Bank One & -2.42 & $\$ 1084.3$ & 9.3 \\
\hline Charles Schwab & -14.26 & $\$ 2564.0$ & 102.2 \\
\hline Deutsche Bank AG & -4.98 & $\$ 8047.4$ & 60.8 \\
\hline Federated Investors & -11.43 & $\$ 387.9$ & 225.9 \\
\hline Franklin Resources & -3.40 & $\$ 375.1$ & -3.9 \\
\hline Gabelli Asset Mgmt. & -2.26 & $\$ 24.6$ & -28.9 \\
\hline ING Groep NV & -5.83 & $\$ 139.4$ & 61.1 \\
\hline Janus Capital Group & -10.96 & $\$ 428.3$ & 224.6 \\
\hline Marsh \& McLennan & -1.59 & $\$ 408.3$ & -5.8 \\
\hline Sun Life Financial & -4.79 & $\$ 704.3$ & 151.3 \\
\hline Wachovia & -1.33 & $\$ 770.2$ & -22.3 \\
\hline Average & -5.14 & $\$ 1356.3$ & 44.6 \\
\hline$p$-value & 0.02 & $0.02 \%$ & 8.93 \\
\hline
\end{tabular}

Source: Center for Research in Securities Prices (CRSP) database for 2003 data. Yahoo! Finance for 2004 data (http:// finance.yahoo.com).

Note: The table measures the announcement period returns and abnormal trading volume for U.S.-traded firms investigated for mutual fund trading abuses. The announcement window begins on day $t-1$ and ends on day $t+2$, where date $t$ represents the initial news date identified in Table I. The abnormal trading volume compares the average daily trading volume over the announcement period to the average daily volume over day $t-50$ to day $t-99$.

\section{Solutions to prevent market timing and future trading abuses}

The SEC is considering several regulatory changes to prevent mutual fund trading abuses. To date, the industry has preferred a combination of trade limitations, short-term redemption fees, and strong language in the prospectus that discourages active trading. We explore the benefits and limitations of several proposals below. We believe that the industry will not completely eliminate these abuses without a comprehensive policy applied consistently across all funds and all investors.

Short-term redemption fees and back-end sales loads

The adoption of short-term redemption fees or back-end sales loads reduces the profitability of market-timing strategies. While the fund industry has favored this approach, it is difficult to guarantee that the fees and monitoring are administered equally to all investors. In addition, while these fees discourage rapid trading, they do not correct the inefficiencies that lead to stale net asset values.

Fees and sales loads increase the cost of mutual fund ownership and are unpopular with customers. Although the SEC caps redemption fees at a maximum $2 \%$ of assets, these charges diminish the competitiveness of mutual funds against a growing array of alternatives such as exchange-traded funds. Redemption fees do not prevent the strategic timing of fund investments or prevent market timers from simply holding a profitable position until the expiration of the redemption window.

\section{Limit the number of round-trip trades}

Many funds limit the number of round-trip trades an investor can make per year. This restriction 
TABLE III

Average monthly returns of investigated and non-investigated mutual funds

\begin{tabular}{lcccc}
\hline & Equity Funds & Balanced Funds & Bond Funds & Money Market Funds \\
Number of Fund Years: & & & & \\
\hline Investigated & 5513 & 491 & 3673 & 1156 \\
$\quad$ Non-Investigated & 19,455 & 1524 & 9473 & 3687 \\
Average Monthly Returns: & & & & \\
\hline Investigated (\%) & -0.21 & 0.08 & 0.48 & 0.15 \\
Non-Investigated (\%) & -0.06 & 0.05 & -0.02 & 0.15 \\
Difference (\%) & -0.15 & 0.03 & 19.95 & 82.85 \\
$p$-value (\%) & 0.77 & 80.48 & & 00 \\
\hline
\end{tabular}

Source: CRSP Survivor-Bias Free Open-End Mutual Fund Database (Jan. 2001 to Dec. 2003)

Note: Mutual funds are sorted by whether or not their fund family was under investigation. Monthly returns are calculated net of operating expenses, ignoring sales loads. We classify funds as equity, balanced, bond or money market based on the asset weights of their holdings and their fund objective as listed by the ICDI. Equity funds include both domestic and international equity funds.

Cumulative mutual fund flows of investigated v. non-investigated funds, month $t$ to $t+6$

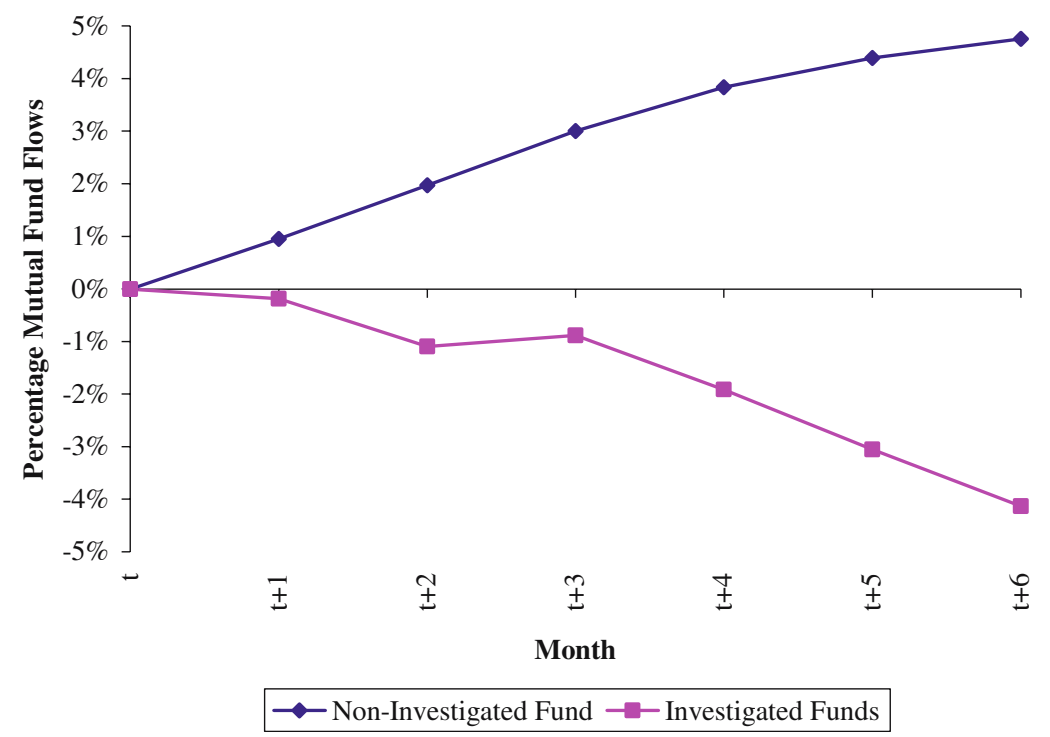

Figure 2. Cumulative mutual fund flows of investigated v. non-investigated funds, month $t$ to $t+6$. Source: CRSP Survivor-Bias Free Open-End Mutual Fund Database. Note: For each investigated mutual fund family, we collect the monthly percentage net inflow from month $t$ (month of the announcement) to month $t+6$ (6 months after) and compare those inflows to the monthly percentage net inflow for the non-investigated funds over that same period. The mean percentage net inflows for the fund families as a whole are calculated as the average of the monthly observations for each family, weighted by each family's total net assets. This is compared to the mean percentage net inflows for the non-investigated funds, calculated in similar fashion. 
discourages, but does not eliminate, excessive trading. Market timers can easily move their trading activity from one fund to another.

Enforcing trade frequency restrictions can be difficult and costly. For example, many variable annuity and $401 \mathrm{~K}$ contracts provide participants with unlimited exchanges among plan assets. Purchases through mutual fund supermarkets and discount brokerage firms also create special challenges. These dealers obscure the identity of fund investors by registering securities in the name of the broker rather than the individual investor. A fund with too many controls may find itself at a competitive disadvantage against less restrictive funds offered through these channels.

\section{Next-day and intra-day fund pricing}

Next-day fund pricing introduces a one-day delay between the receipt of a purchase or redemption order and the transaction execution. Kadlec (2004) states that delayed pricing removes the predictability of NAVs and exposes fund timers to an additional day of risk. This approach is simple and inexpensive to implement, but it introduces additional costs on investors. Most notably, next-day pricing diminishes liquidity, placing mutual funds at a large disadvantage relative to exchange-traded funds during periods of high volatility.

With regards to pricing frequency, exchangetraded funds (ETFs) lie at the other end of the spectrum, trading throughout the market day. Mutual funds could presumably enhance their competitiveness with more frequent intra-day pricing. However, in addition to raising the administrative costs, intra-day cash flows increase the indirect costs of managing the portfolio and providing liquidity. Cash inflows that are not immediately invested leave the manager subject to tracking error. For international funds, a cheaper alternative is to simply price the fund as of the local market close rather than 4:00 p.m. Eastern Time.

\section{Fair value pricing}

Fair value pricing is the most widely advocated solution in the literature to prevent market timing.
Chalmers et al. (2001), Goetzmann et al. (2001), and Zitzewitz (2003a), among others, all propose efficient pricing mechanisms that incorporate additional information available at the time NAVs are computed. This approach essentially leaves the NAV uncorrelated with market information. By removing the predictable portion of the next day's NAV, fair value pricing eliminates the profitability of short-term trading strategies.

\section{Aligning managerial and shareholder interests}

The mutual fund scandal enveloped a large portion of the industry. Regulatory attention to date has focused mainly on structural changes to eliminate these specific trading abuses. A broader and largely unanswered question is why some firms engaged in these abuses while others did not? What role, if any, did corporate structure and corporate culture play in the scandal? This issue certainly warrants additional study.

Mutual funds collect management fees as a percentage of total portfolio assets. These revenues increase proportionally with assets under management and are not directly tied to performance. Thus, it is not surprising that the industry favors wealthier clients or institutional investors with greater assets. Several firms implicated in the mutual fund scandal actively "sold" market timing capacity to key investors in exchange for large deposits of "sticky" or long-term assets in other high-fee funds. Many of these arrangements were initiated at the corporate level, placing the sales staff at odds with individual fund managers, who often are compensated based on their portfolio returns.

Firms that allow late trading and market timing of their mutual funds place corporate profits above their fiduciary duties to investors. ${ }^{16}$ Interestingly, all of the investigated fund families examined in this study are either privately held or are subsidiaries of large financial institutions. Mutual or shareholderowned organizations appear largely uninvolved in the scandal. With increased consolidation of the financial services industry, corporate ownership of asset management firms is unlikely to change. Linking asset management revenues to fund performance helps align the interests of management with shareholders and may prevent future trading abuses. 


\section{Conclusion}

Mutual funds have been one of the fastest growing segments of the financial services industry over the last 20 years. The Investment Company Institute (ICI) estimates that by the end of 2003 more than 53.3 million, or $47.9 \%$, of U.S. households owned mutual funds. The total value of these investments was \$7.414 trillion. Mutual funds are also the vehicle of choice for the vast majority of retirement accounts.

As the reach and influence of this industry grows, it is perhaps more important than ever to ensure that funds are managed ethically and serve the best interests of all investors. The mutual fund trading scandal questions whether the industry is serving its shareholders or its own interests.

Both late trading and market timing are relatively simple problems to fix. The SEC is currently considering a "hard" close at 4:00 p.m. for all mutual fund investors. Strict enforcement of this deadline implies that no trades, under any circumstances, would be allowed after the market close. This change in enforcement would effectively eliminate late trading abuses.

To eliminate market timing schemes, we propose that the industry employ a two-pronged approach that combines fair value pricing with mandatory short-term redemption fees. Fair value pricing has actually been available to mutual funds since 1981, yet without clear guidance or consistent implementation procedures, the industry has been hesitant to adopt the approach. Since fair value pricing requires mutual fund investors to accept the estimated NAV on faith, investors need assurance that the technique is applied uniformly across all funds and market circumstances. For this reason, we suggest that the SEC focus its regulatory efforts on devising a pricing policy that incorporates not only the latest available financial information but also one that utilizes the latest information technologies. The long-term stability of the mutual fund industry likely depends on its ability to restore investor confidence while remaining competitive against a growing number of investment alternatives.

\section{Acknowledgements}

We thank Ann Tenbrunsel, the referee and seminar participants at the Ethical Dimensions in Business:
Reflections from the Business Academic Community conference at the University of Notre Dame for helpful comments and suggestions.

\section{Notes}

1 See "State Investigation Reveals Mutual Fund Fraud: Secret Trading Schemes Harmed Long-Term Investors," Office of New York State Attorney General Elliot Spitzer, September 3, 2003. http://www.oag.state.ny.us/press/2003/sep/sep03a_03.html

2 For an online summary of the mutual fund trading scandal, see Morningstar's "Fund Industry Investigation Update" (http://www.morningstar.com/fii/fundindustryinvestigation.html) or The Wall Street Journal's "Mutual Fund Scandal Scorecard" (http:// interactive.wsj.com/documents/info-mfsc04.html).

3 For a more formal discussion of the securities regulations affecting the mutual fund industry, see Ogden and O'Hagan (1997).

4 Zitzewitz (2003b) notes that prior to 1968, most mutual funds employed "backward" pricing, clearing trades at the most recent prior net asset value. Interestingly, forward pricing was adopted to protect long-term shareholders from potentially dilutive trading strategies designed to exploit these stale fund prices.

5 See supra note 1.

6 See Complaint, State of New York v. Canary Capital Partners, LLC, Canary Investment Management, LLC, Canary Capital Partners, LTD and Edward J. Stern. (http://www.oag.state.ny.us/press/2003/sep/

canary_complaint.pdf)

7 See Testimony Concerning Recent Commission Activity to Combat Misconduct Relating to Mutual Funds, Stephen M. Cutler, Director, Division of Enforcement, U.S. Securities and Exchange Commission, Before the Senate Subcommittee on Financial Management, the Budget, and International Security, Committee on Governmental Affairs, Nov. 3, 2003. (http://www.sec.gov/news/ testimony/ts110303smc.htm)

8 The Putnam Growth Fund, 1981 SEC No-Act. LEXIS 3088 (Feb. 23, 1981).

9 For example, see Bhargava et al. (1998), Bhargava and Dubofsky (2001), Chalmers et al. (2001), Goetzmann et al. (2001), Boudoukh et al. (2002), Greene and Hodges (2002), and Ziztewitz (2003a), among others.

10 See supra note 1.

11 Columbia was a subsidiary of FleetBoston Financial. Ironically, at the time these allegations surfaced, FleetBoston was in the process of being acquired by Bank of America. The Columbia umbrella includes the Acorn, 
Colonial, Columbia, Galaxy, Liberty, Newport, and Stein Roe family of funds. See Civil Action No. 04 CV 10367-GAO, S.E.C. v. Columbia Management Advisors, Inc., and Columbia Funds Distributor, Inc. (http:// www.sec.gov/litigation/complaints/comp18590.htm).

12 In a spring 2000 email to the fund advisor, the liaison for the Stein Roe International fund noted that "for the last 6 weeks... \$142,018,026 has gone into the Fund and $\$ 134,935,372$ has gone out.... These figures exceed the total size of the Fund (sec. 66b)!" In August 2000, the portfolio manager for the Newport Tiger Fund complained about market timers to the advisor and distributor, noting "Their active trading has increased and it has become unbearable. There will be long term damage to the fund. Let's understand that they really are not investors (sec. 66c)." (http:// www.sec.gov/litigation/complaints/comp18590.htm) 13 See "Alliance Agreement Includes New Form of Relief for Shareholders: \$600 Million Agreement Includes 20 Percent Reduction in Mutual Fund Fees," Office of New York State Attorney General Elliot Spitzer, December 18, 2003. http://www.oag.state.ny.us/ press/2003/dec/dec18c_03.html

14 Seven mutual fund families are privately held. Two parent firms, Old Mutual PLC (U.K.) and CDC Asset Management (France) are foreign-listed and do not trade in the U.S. Data for FleetBoston Financial was unavailable due to its recent acquisition by Bank of America.

15 The investigated firms managed 4250 funds and fund share classes during the September 2003 to June 2004 period. With an average expense ratio of $1.42 \%$, these declines translate into $\$ 844.7$ million $(\$ 14.0 \times 1.42 \% \times 4,250)$ of combined revenue losses over the 6-month, post-announcement period. Over a 9-month window, each fund lost $\$ 16.2$ million in average assets, while the investigated firms suffered total revenue declines of more than $\$ 977.2$ million $(\$ 16.2 \times 1.42 \% \times 4,250)$.

16 Morningstar recently added a fiduciary ranking into its mutual fund rating system. The fiduciary grade for each fund is based on five components: regulatory actions, board quality, manager incentives, fee structure, and corporate culture (http://quicktake.morningstar.com/DataDefs/FidGradeMethodology.pdf).

\section{References}

Bhargava, R., A. Bose and D. A. Dubofsky: 1998, 'Exploiting International Stock Market Correlations with Open-End International Mutual Funds', Journal of Business Finance and Accounting 25(5-6), 765-773.

Bhargava, R. and D. A. Dubofsky: 2001, 'A Note on Fair Value Pricing of Mutual Funds', Journal of Banking and Finance 25(2), 339-354.

Boudoukh, J., M. Richardson, M. Subrahmanyam and R. F. Whitelaw: 2002, 'Stale Prices and Strategies for Trading Mutual Funds', Financial Analysts Journal 58(4), 53-71.

Chalmers, J. M. R., R. M. Edelen and G. B. Kadlec: 2001, 'On the Perils of Financial Intermediaries Setting Security Prices: The Mutual Fund Wild Card Option', Journal of Finance 56(6), 2209-2236.

Goetzmann, W. N., Z. Ivković and K. G. Rouwenhorst: 2001, 'Day Trading International Mutual Funds: Evidence and Policy Solutions', Journal of Financial and Quantitative Analysis 36(3), 287-309.

Greene, J. T. and C. W. Hodges: 2002, 'The Dilution Impact of Daily Fund Flows on Open-End Mutual Funds', Journal of Financial Economics 65(1), 131158.

Kadlec, G. B.: 2004, 'On Solutions to the Mutual Fund Timing Problem', Virginia Polytechnic Institute Working Paper.

Ogden, T. P. and C. J. O’Hagan: 1997, 'Mutual Funds Confront Dilemmas in Trying to Value Portfolios; SEC Needs to Provide Updated Guidelines', New York Law Journal 15, 1-7.

Zitzewitz, E.: 2003a, 'Who Cares About Shareholders? Arbitrage-Proofing Mutual Funds', Journal of Law Economics and Organaization 19(2), 245-280

Zitzewitz, E.: 2003b, 'How Widespread is Late Trading in Mutual Funds?', Stanford University Working Paper.

Todd Houge

Department of Finance, Henry B., Tippie College of Business, S288 PBB, Iowa City, IA, 52242-1000, U.S.A, E-mail: todd-honge@uiowa.edu

Jay Wellman Binghamton University, A-316 School of Management, Binghamton, NY, 13902, U.S.A, E-mail:jwellman@binghamton.edu 